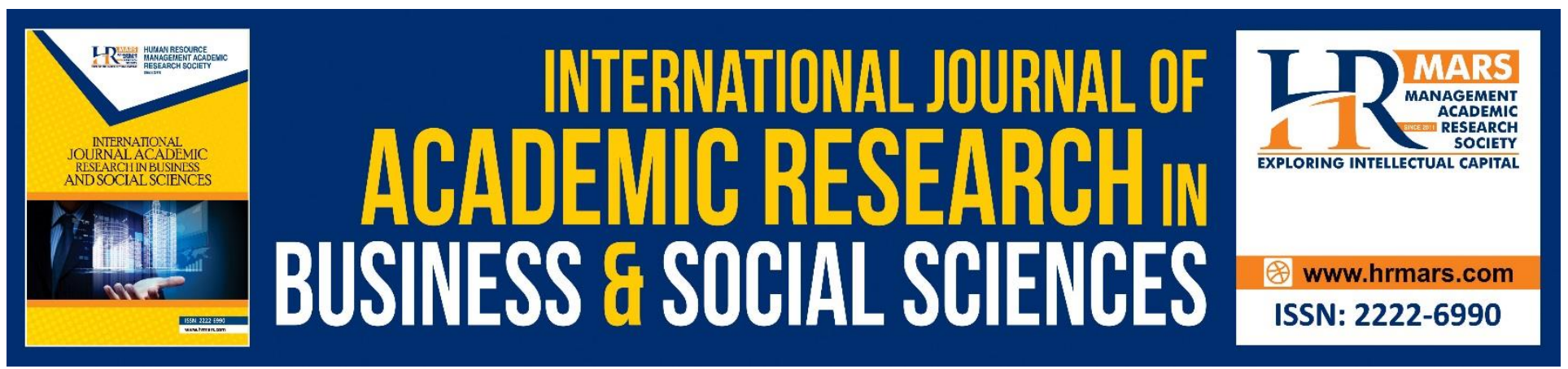

\title{
Model of Fire Safety Management for the Assessment of an Office Building in FCT Abuja Nigeria
}

\author{
Alao, Mohammed Kaseem, Yahya Mohamad Yatim and Wan Yusoff Wan \\ Mahmood
}

To Link this Article: http://dx.doi.org/10.6007/IJARBSS/v10-i8/7542

DOI:10.6007/IJARBSS/v10-i8/7542

Received: 25 May 2020, Revised: 26 June 2020, Accepted: 20 July 2020

Published Online: 27 August 2020

In-Text Citation: (Alao, Yatim, and Mahmood, 2020)

To Cite this Article: Alao, M. K., Yatim, Y. M., and Mahmood, W. Y. W. (2020). Model of Fire Safety Management for the Assessment of an Office Building in FCT Abuja Nigeria. International Journal of Academic Research in Business and Social Sciences. 10(8), 333-340.

Copyright: (c) 2020 The Author(s)

Published by Human Resource Management Academic Research Society (www.hrmars.com)

This article is published under the Creative Commons Attribution (CC BY 4.0) license. Anyone may reproduce, distribute, translate and create derivative works of this article (for both commercial and non-commercial purposes), subject to full attribution to the original publication and authors. The full terms of this license may be seen at: http://creativecommons.org/licences/by/4.0/legalcode

Vol. 10, No. 8, 2020, Pg. 333 - 340

http://hrmars.com/index.php/pages/detail/IJARBSS

JOURNAL HOMEPAGE

Full Terms \& Conditions of access and use can be found at http://hrmars.com/index.php/pages/detail/publication-ethics 


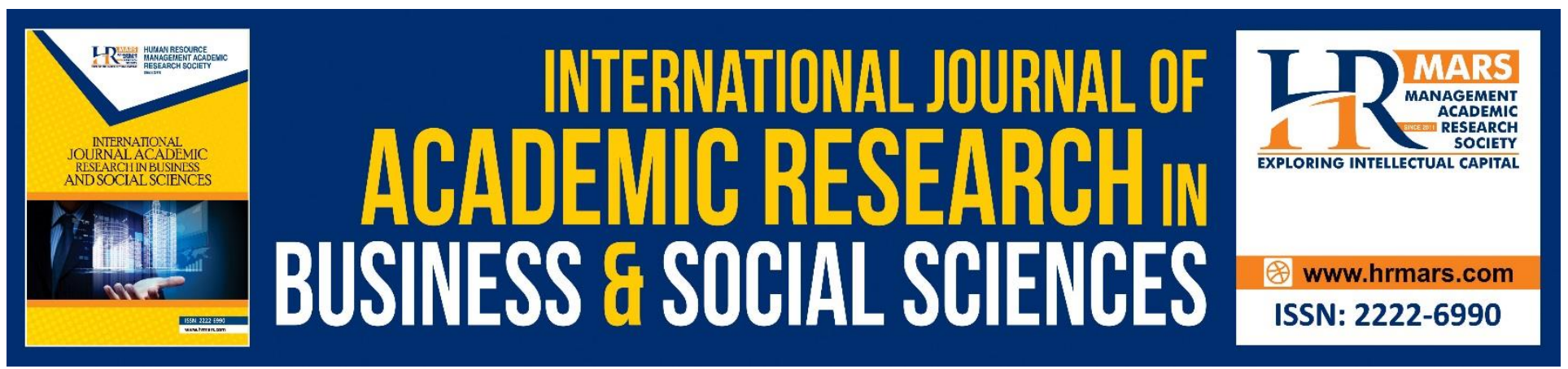

\title{
Model of Fire Safety Management for the Assessment of an Office Building in FCT Abuja Nigeria
}

\author{
Alao, Mohammed Kaseem, Yahya Mohamad Yatim and Wan Yusoff \\ Wan Mahmood \\ Department of Quantity Surveying, Faculty of Built Environment and Surveying \\ Universiti Technologic Malaysia \\ Email:kaseem@graduate.utm.my,b-yahya@utm.my,b-wyusof@utm.my.
}

\begin{abstract}
Fire safety management is essential in the aspects of achieving absolute fire safety standards in a building. Various Fire safety assessment methodologies and fire risk evaluation process has been developed over time, in spites of this, the fire risk keeps increasing, which implied that, there is a poor fire safety management. This study proposes a model of fire safety management for the fire risk assessment of an office building in Nigeria. The ten components of fire safety management were selected from the literature review, which was later structured to form criteria. The relative importance index was used to rank the level of compliance of fire safety management base on their influence. The questionnaires were the distribution to 30 fire safety practitioners and experts with substantial experience and knowledge in fire safety management. The data were analyzed using the relative importance index analytical approach. The evaluation model was suggested base on fire safety practitioners and experts' perceptions. The inspection/observation of an office building was conducted in Nigeria in order to validate the model. The findings revealed that there is higher fire risk due to non- compliance with the standard fire safety management.
\end{abstract}

Keyword: Office Building, Component of FSM, Relative Importance Index, Assessment.

\section{Introduction}

Approaches differ from inspection checklists, point scheme (Society, 2015). Fire is critical for human development, national and society and it is an essential aspect of social development among several kinds of disasters fire constitutes a significant threat to life, property, and environment. The report from fire services department in 2018, shows a total of 51400 numbers of fire calls and 934 fire death (NFPA, 2018), building fire particularly in public buildings remain a critical concern as the fire outbreak revealed between 2013 and 2018 indicate the significant increase in the fire disasters and the numbers of death (Emmanuel, Tulasie, \& Jeboah, 2016). The government and other stakeholders have a responded to an increase in fire risk using several approaches, which include building regulations, fire safety code, fire safety training, and holistic fire safety management and construction/design to prevent fire occurrences. 
INTERNATIONAL JOURNAL OF ACADEMIC RESEARCH IN BUSINESS AND SOCIAL SCIENCES Vol. 10, No. 8, 2020, E-ISSN: 2222-6990 @ 2020 HRMARS

The specific intervention of the Nigerian government is to encourage the development of fire risk management systems in buildings, prevents, protect, and effective management of fire, to reduce the risk to lives, property destruction, and business continuity. Hence, ensuring buildings fire safety.

Despite several intervention by the stakeholders by conducting an evaluation of fire safety in the existing building, especially office building, the problems of fire safety management are not adequately addressed (Chen, Chuang, \& Huang, 2012). According to (Service, 2015), evidence has shown the significant factors contributing to incidences of fire outbreak or disaster (Badger, 2017), as several researchers proved that the highest percentages of the catastrophe were caused as a result of human errors. While, lower rates show to be a technical failure. In addition, the primary sources of several building fire disasters are fire safety management which usually not properly not implemented $(G, 1999)$, fire safety regulation did not adequately address; the code contained minimal aspects of fire safety management and did not take into consideration the significance of fire safety management at the post-construction stages of the building. As a result, practical fire safety management could not be fully enforced as an aspect of fire safety regulations.

However, the existing fire safety regulation and provided aspects of management issues in specifics buildings. Therefore, it is not adequate to achieve fire safety objectives (Malhotra, 1993). Fire safety management was also provided in the health and safety at work act, but only captured the aspect of the safety of employee (Porter, 1990)

Even though the safety of occupants is essential, protection against the destruction of property and closures of business because of fire, disaster is also paramount because fire disaster can result in total destruction like the collapse of buildings (Wong \& Xie, 2014). In the UK tower, fire outbreak in the 14 June 2017 in the 24 stories Grenfell Tower, a block of office buildings in North Kensington, West London, United Kingdom. The authority confirmed that $80 \%$ of occupants died due to the fire disaster

Therefore, the event will be remembered in history as one of the historical fire disasters alongside the shanghai apartment fire in 2010.Furthermore, the report from the UK revealed that direct materials damages because of the fire are nearly $0.21 \%$ gross of domestic product annually. In addition, fire disasters could result in significant losses to buildings, which can be so complex to evaluate. Thus, these comprise social-economic damage, closure of daily business activities, and loss of a job.

Fire safety management can be described as an application by the manager of policy, standards, tools, information, and practice to the task of analyzing, evaluating, and controlling fire safety ( (Howarth \& Kara-Zaitri, 1999). Therefore, the management of fire is a whole process throughout the life cycles of buildings in order to achieve the acceptable level of fire safety objectives Chow (2001), According to (Wardani \& M.Dachyar, 2018), describe the management as an act of managing human and materials toward achieving the organizational goals and objectives, the studies declared that its task is to carry out the necessary action to achieve the fundamental purpose of the organization

However, it can be concluded that fire safety management in the organization aims at preventing fire disasters and damage to property, environment, and occupants' death or injuries because of fire (Wambugu, Mburu, \& Galebe, 2016). Fire safety management is developed primarily on subjectivity, as the assessment of one person is applicable based on his knowledge and experience if the evaluation is good or bad, unlike objective evaluation, which is based on a particular guideline. However, in ensuring that a subjective is satisfactorily understood, it must be express in number 
INTERNATIONAL JOURNAL OF ACADEMIC RESEARCH IN BUSINESS AND SOCIAL SCIENCES Vol. 10, No. 8, 2020, E-ISSN: 2222-6990 @ 2020 HRMARS

(Kodur, Kumar, \& Rafi, 2019). Hence, this is closer to objectives judgment/ comprehensiveness of fire safety management.

Because of this, the assessment of fire safety management in office buildings using quantitative data analysis is critical, particularly in developing countries where proper fire safety management was not considered. In Nigeria, fire safety in a public building, especially office building, is generally poor. Therefore, fire safety management evaluation can provide better approaches to determining the level of fire safety in office buildings. Office buildings are under high fire risk. Thus, determining the level of potential fire risk is critical in achieving fire safety objectives.

\section{Methodology}

The research selected ten components (as shown in Table) of fire safety management from the literature review Howarth (1999), and the components adopted were used to prepare a questionnaire using likers scale. Thirty (30) fire safety practitioners and experts in the field of fire with knowledge and experience were selected to participate in the aspect of fire safety management; the thirty experts were involved in the survey. The fire safety experts were asked to rank the ten components of fire safety management components selected for the survey according to their level of importance. The expert's response was collected and analyzed using the relative importance index. The physical inspection was then conducted in one of the office buildings using an observation checklist based on the ten components of fire safety management. The ranking value from the physical inspection with the correspondent relative importance index of each component obtained from the perception of the fire safety experts were presented in Table,1,2 and Figure 1

Table 1. Physical observations Checklist

\begin{tabular}{|c|c|c|c|c|}
\hline \multirow{2}{*}{$\begin{array}{l}\text { Evaluation Criteria } \\
\text { Adequate fire safety system in place }\end{array}$} & \multicolumn{2}{|c|}{$\begin{array}{l}\text { Observation } \\
\text { result } \\
\text { YES NO }\end{array}$} & \multicolumn{2}{|c|}{$\begin{array}{l}\text { Observation result } \% \\
\text { YES \% NO } \%\end{array}$} \\
\hline & - & 1 & 0 & 10 \\
\hline Adequate fire safety system in place & - & 1 & 0 & 10 \\
\hline Qualify fire safety management appointed & - & 1 & 0 & 10 \\
\hline a Does occupants aware of fire safety & 1 & - & 10 & 0 \\
\hline Are the fire safety system maintain & - & 1 & 0 & 10 \\
\hline $\begin{array}{l}\text { Implementing emergency incident and post } \\
\text { event }\end{array}$ & 1 & - & 10 & 0 \\
\hline $\begin{array}{l}\text { Is there risk training conducted on } \\
\text { regulation bases. }\end{array}$ & 1 & - & 10 & 0 \\
\hline Good fire safety policy & - & 1 & 0 & 10 \\
\hline $\begin{array}{l}\text { Are incidents of fire reported and } \\
\text { investigated }\end{array}$ & 1 & - & 10 & 10 \\
\hline Total level of compliance: & 4 & 6 & $40 \%$ & $60 \%$ \\
\hline
\end{tabular}

\section{The Results and Discussion}

The results from the physical observation shown in Table 1 indicate that the level of implementation of adequate fire safety management components is $40 \%$, as against $100 \%$, benchmark which implied that the level of compliance with the standard fire safety management system is inadequate. 
INTERNATIONAL JOURNAL OF ACADEMIC RESEARCH IN BUSINESS AND SOCIAL SCIENCES Vol. 10, No. 8, 2020, E-ISSN: 2222-6990 @ 2020 HRMARS

However, the acceptable results for the fire safety management compliance should range from 50 $100 \%$. The evidence from the result show that urgent improvement is required in the office building in terms of fire safety management system. In addition, the finding from the physical observation also implied that the level of fire risk expose to by the occupant of the building, which could eventually lead to death, injury in the event of fire is very high.

Secondly, the table (2) and figure (1), shows the finding from the level of importance of the components of fire safety management from the perception of fire safety practitioners and experts from Lagos state Nigeria. The results from these sections of the study are contrary to the finding from Aminu (2014), (Baker \& Bouchlaghen, 2013) with the most influential components of fire safety management as fire risk assessment, emergency plan/procedures. While, maintenance of fire equipment and standard, become the most influential components in the study as indicated in the figure (1), this is because of differences in the background of the experts that participated in the survey, furthermore, the method used in the data collection, analysis region in which they were conducted.

Table 2 the level of FSM component importance

\begin{tabular}{|c|c|c|c|c|c|}
\hline s/no & Components of FSM & $\begin{array}{l}\text { Relative } \\
\text { important } \\
\text { index }\end{array}$ & $\begin{array}{l}\text { Items } \\
\text { means }\end{array}$ & Ranking & Status \\
\hline 1 & Fire risk assessment & 0.49 & 2.5 & $6^{\text {th }}$ & Low-effective \\
\hline 2 & Fire Safety organization & 0.60 & 3.0 & 2rd & Highly effective \\
\hline 3 & $\begin{array}{l}\text { Compliance with fire } \\
\text { safety regulation }\end{array}$ & 0.42 & 2.1 & $8^{\text {th }}$ & Non-effective \\
\hline 4 & $\begin{array}{l}\text { Emergency plan/fire } \\
\text { safety procedure }\end{array}$ & 0.45 & 2.3 & $7^{\text {th }}$ & Non-effective \\
\hline 5 & $\begin{array}{l}\text { Fire safety } \\
\text { communication/ } \\
\text { information }\end{array}$ & 0.49 & 2.5 & $6^{\text {th }}$ & Low-effective \\
\hline 6 & $\begin{array}{l}\text { Reporting and } \\
\text { investigating fire }\end{array}$ & 0.57 & 2.8 & $3^{\text {th }}$ & Moderately Effective \\
\hline 7 & Fire Safety Training & 0.53 & 2.6 & $5^{\text {th }}$ & Moderately -effective \\
\hline 8 & $\begin{array}{l}\text { Maintenance of Fire } \\
\text { equipment and standard }\end{array}$ & 0.65 & 3.2 & $1^{\text {st }}$ & Highly effective \\
\hline 9 & Fire Safety Audit & 0.56 & 2.7 & $4^{\text {th }}$ & Moderately -effective \\
\hline 10 & Fire Safety Budget & 0.60 & 3.0 & 2rd & Effective \\
\hline
\end{tabular}


INTERNATIONAL JOURNAL OF ACADEMIC RESEARCH IN BUSINESS AND SOCIAL SCIENCES Vol. 10, No. 8, 2020, E-ISSN: 2222-6990 @ 2020 HRMARS

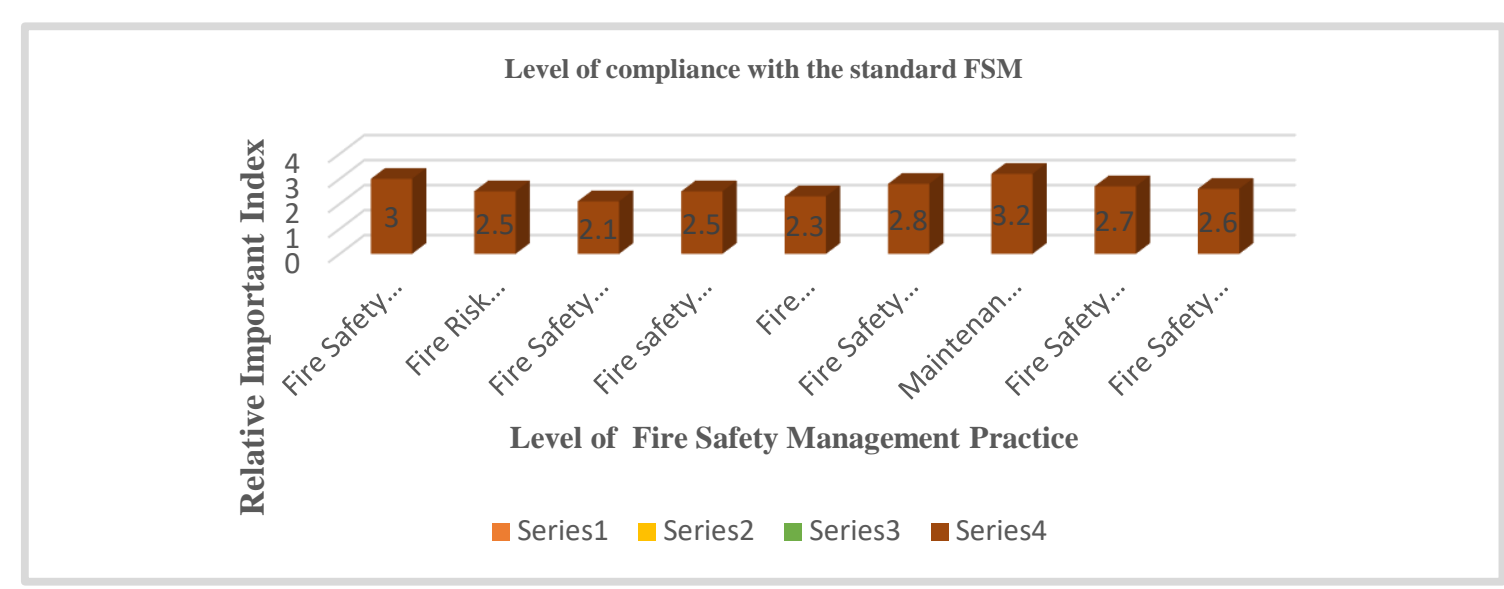

Figure 1: showing the results of level of FSM practice

\section{Fire Safety Management Evaluation Models Component}

The model was developed from the ten most influential components of fire safety management the observation checklist and questionnaires survey was distributed to the nominated fire safety experts, and fire safety practitioners were the principal foundations of the model, which generate the ranking results and the result of relative importance index from the participant's perception respectively.

The results were used to assess the level of fire risk of one of the Nigerian office buildings.

Figure (1), represent the evaluation process. 
INTERNATIONAL JOURNAL OF ACADEMIC RESEARCH IN BUSINESS AND SOCIAL SCIENCES Vol. 10, No. 8, 2020, E-ISSN: 2222-6990 @ 2020 HRMARS

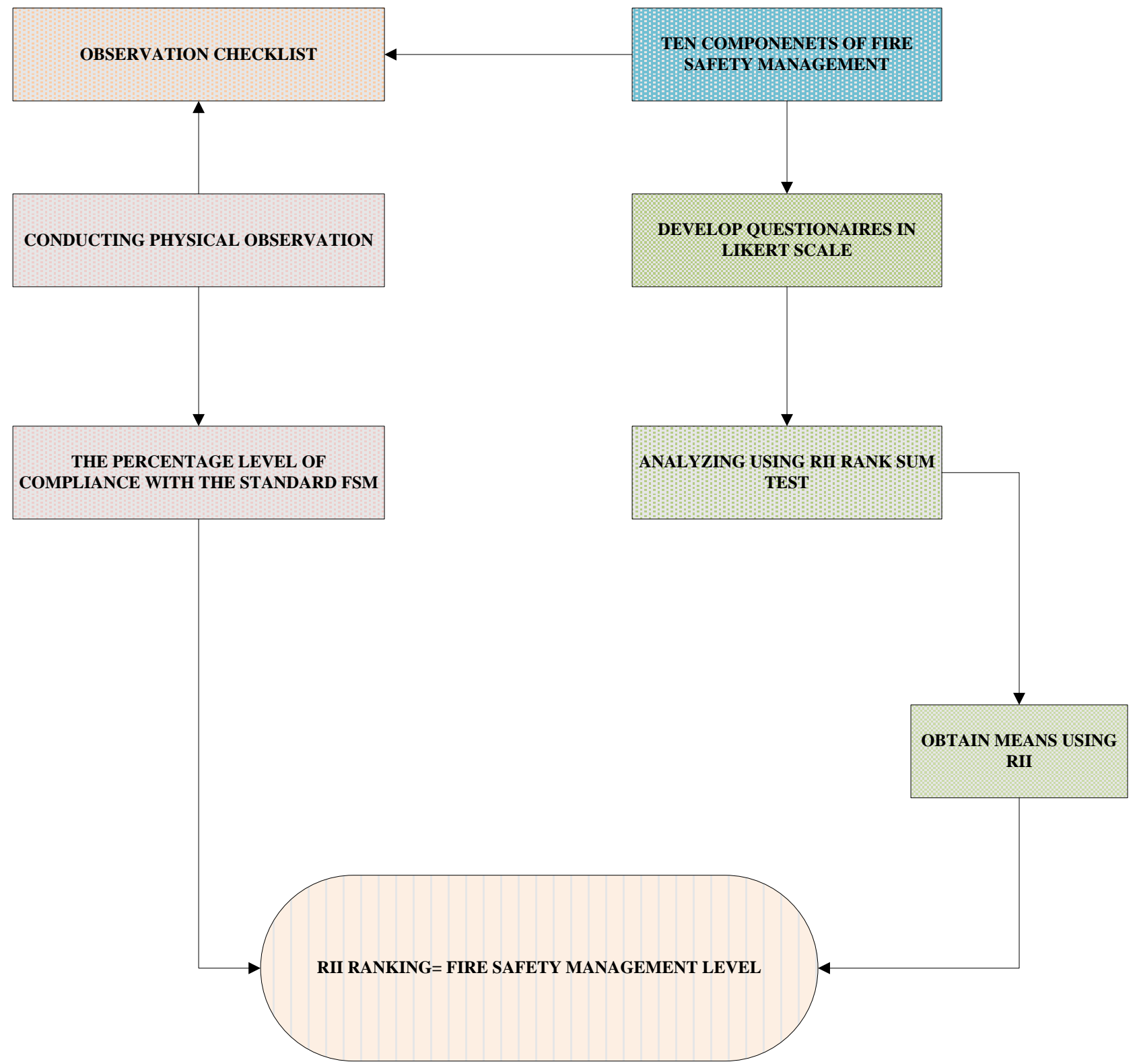

Figure 2: Model of Fire Safety Management

\section{Conclusion}

This research was carried out to propose a model for fire safety management evaluation of existing public office buildings in Nigeria. Therefore, analyzing the level of compliance of the office building with fire safety management through observation checklist and examined the fire safety level of the office buildings based on the ten most influential fire safety management components adopted from the literature.

However, several studies have revealed that the experts' perception survey and conducting an observation a prove that evaluation of fire safety management in any buildings should be based on numerical interpretation. Hence, the model of fire safety management evaluation developed from this research can be applied to any other types of buildings, provided that the ten components of fire safety management program are useful for all buildings types. Thus, the study comes up with a fire 
INTERNATIONAL JOURNAL OF ACADEMIC RESEARCH IN BUSINESS AND SOCIAL SCIENCES Vol. 10, No. 8, 2020, E-ISSN: 2222-6990 @ 2020 HRMARS

safety management evaluation model for an existing buildings in Nigeria, thereby contributing to the scholarly literature requesting for the development of strategies for determine the level of fire risk in buildings, particularly in Nigeria, and it has exhumed the strategies necessary for the achievement of fire safety objectives by the building managers, and fire safety practitioners in Nigeria at postconstruction stage of the building.

\section{Acknowledgement}

The unwavering efforts of all the authors of this paper are highly recognized especially the positive contributions and guiding roles of the second and the third author, and researchers would like to appreciate the support of the TRG Campus from UTM through cost center No R.J 130000.7751.4J343.

\section{References}

Badger, S. (2017). Large loss of fire and explosition . NFPA Journal .

Baker, J., \& Bouchlaghen, D. a. (2013). Categorization of Fire Safety Management: Results of a Delphi Panel. Fire Safety Journal.

Chen, Y.-y., Chuang, Y.-j., \& Huang, C.-a. (2012). The adoption of fire safety management for upgrading the fire safety level of existing hotel buildings. Building and Environment.

Emmanuel, K. A., Tulasie, S. K., \& Jeboah, J.-S. A. (2016). Trend of fire outbreak in Ghana and ways to prevents it. Safety-Health work Journal .

G, R. (1999). Fire Safety Management and Risk assesment Facilities.

Howarth, D., \& Kara-Zaitri, C. (1999). Disaster Prevention and Management . An International Journal .

Kodur, V., Kumar, P., \& Rafi, M. M. (2019). Fire Hazard in Building: review assesment and Strategies for improving fire safety. Emerald Journal.

Malhotra, H. (1993). Proposed Code for Fire Safety in Building for the State of Sao Paulo. AGNICONSULT, (pp. 1-98).

NFPA. (2018). Fire Department Calls Statisrtics. National Fire Protection Association.

Porter, A. (1990, 8 2). Management of fire safety property Management. pp. 154-158.

Service, N. (2015). Fire Science and Ventilation Study Guilde. Wellington.

Society, A. C. (2015). Identifying and Evaluating Hazard in Research Labouratories.

Umar, A., Embi, M. R., \& Yatim, Y. M. (2014). Fire Safety Management Evaluation Model Existing Plastic Factory Building in Nigeria. Applied Mechanic and Materials, 732-737.

W.K, C. (2011). Review on fire safety management and application to Hong Kong. International Journal on Engineering Performance-Based Fire Codes, 52-58.

Wambugu, F., Mburu, \& Galebe, E. (2016). Assesment of Fire Safety Preparedness at Jomo Kenyatta International Airport. JAGST, 2.

Wardani, T. K., \& M.Dachyar, R. N. (2018). Jakarta Fire Safety System Management Practices for High-Rise Building. 2018 IEEE 5TH International Conference on Engineering Technologies and Applied Science, (pp. 22-23). Thailand.

Wong, K. H.-I., \& Xie, D.-y. (2014). Fire Safety Management Strategy of Complex Developments. Procedia Engineering, 410-420. 